\title{
THE JUNIOR HIGH SCHOOL IN HOUSTON, TEXAS
}

P. W. HORN

Superintendent of Schools, Houston, Texas

[Editor's Note.-Superintendent P. W. Horn, of Houston, Texas, has sent a copy of his report to the Board of Education of that city to the Journal, with permission to print in full the statement which he makes to the Board regarding the junior high school.]

Year before last we determined to inaugurate the policy of junior high schools and we erected two magnificent junior high-school buildings. These schools were intended to meet the needs of that large group of children for whom neither the high school nor the elementary school has previously made adequate provision, and many of whom have as a result been dropped out of school. One of the prominent features in our history during the past school year has been our effort to carry out the junior high-school idea and to meet more nearly the needs of the children of this group.

It is needless to say that this task has not as yet been fully completed. School systems do not ordinarily grow by revolution or by miracle. Their perfecting is a matter of steady growth and slow development. While I am sure that our junior high schools have accomplished a great deal during the past year, I am equally sure that it will take several years for them to become fully established and several years more for their results to be fully measured or appraised.

During the past year I have received letters from all over the United States, from Maine to California, asking about the success of our junior high-school plan. In many instances questions were asked calling for detailed information as to the number of boys and girls who would have otherwise dropped out of school, but had been retained in school by the junior high-school plan. To all of these I have replied stating that it is impossible to judge of the success of any educational plan after it has been in operation only a few weeks 
or months. No educational institution which is worth establishing can be established in fifteen minutes, or even in fifteen weeks or months.

One of the first things which our experience showed is that you cannot establish a junior high school by merely cutting off one year of the elementary school and two years of the high school, putting these grades under one building and calling them a junior high school.

There might or might not be a certain amount of good in this simple process, but its effect for either good or evil would be very limited. The junior high school is not an elementary school. Neither is it a high school. Neither is it a sort of a mixture of the two in equal proportions. If it is in reality an institution worthy of its place in our educational economy, it is an institution which is neither an elementary school nor a high school, but a provision for the needs of those children for which neither of the older institutions made suitable provision. It partakes to some extent of the nature of each, but it is essentially different from either.

If anyone were to ask by what particular means the junior high school proposes to meet the needs of this large group of pupils, the following may be mentioned:

By using methods of instruction more mature than those generally used in elementary schools, yet less mature and less like university methods than those commonly used in the high schools.

By using methods of discipline and control that are not such as are generally used with small children, and yet not such as are sometimes used in high schools.

By keeping in school through this critical period many boys and girls who would ordinarily drop out on account of lack of provision for their needs at this special time. The junior high school is a failure unless it points distinctly to the senior high school, and urges all those pupils to complete its course who can.

By furnishing a convenient stopping-place for those pupils who cannot remain in the high school for four years, keeping them in school at least a year or two longer than they would otherwise stay, and allowing them to drop out at the end of that time with at least a fairly good equipment for entering into the competitions of the modern industrial world. 
By furnishing more men teachers for the boys of the upper grades in the intermediate schools.

By furnishing greater elasticity in the course of study in the upper intermediate grades, with greater freedom of election both there and in the earlier years of the high school.

By allowing the brighter pupils in the seventh grade to begin work in certain high-school subjects sooner than they otherwise would. This is particularly true of the work beginning a foreign language.

By bringing the high school geographically nearer to the child's own home. Some children do not enter high school merely on account of the distance of the high-school building from the child's home. The fact that one of our junior high schools is located in the South End of our city and the other on the North Side is a decided advantage.

By laying greater emphasis upon education along industrial lines and along physical lines.

Last, but by no means least, by laying greater emphasis upon the treatment of the child as an individual than seems to be possible in the average large city high school of the ordinary type. Any junior high school that fails to emphasize the idea of the personal touch and the plan of individual teaching is foredoomed to failure.

As has been stated, we have just completed our first year of work with junior high schools, and it is even yet too early to speak definitely of results. It is interesting to observe that we have had an enrolment of $\mathrm{I}, 648$ white pupils in the grades formerly known as highschool grades, as compared with I,34I of the year preceding. This shows an increase of 307 , or about 23 per cent, which is slightly more than double the rate of increase in the schools as a whole. This, of course, does not include the seventh-grade pupils enrolled in the junior high-school building. However, it is the next year and the years following that must tell the real story of the success of the junior high school as a means for holding pupils in school.

Our junior high-school buildings have been admirably planned and equipped for the purposes outlined above. Especially are they adapted to the policy of emphasizing industrial education and physical education. They have much greater proportion of their space 
given to shops, kitchens, laboratories, gymnasiums, and assembly rooms than is ordinarily found in school buildings. In our South End building in particular it would have been possible to erect a building to accommodate at least 50 per cent more students with the $\$ 250,000$, which the building cost, in addition to the grounds and equipment. This would have been done, however, by adding more classrooms at the expense of shops, laboratories, etc.

One of the most attractive features at our South End junior high school, as well as one of the most used and one of the most useful, is the swimming-pool. It is recommended that this feature be also added to our North Side junior high school. In our far southern climate a swimming-pool can be used almost the year around, and is a much more important factor in health, education, and recreation than it is in places farther north.

The chief difficulty in the way of making the junior high school reach its full measure of success lies in establishing a clear-cut junior high-school idea in the minds of all concerned. It is by no means easy to get the teachers to understand fully just what they are trying to do. The idea too frequently is that the junior high school is merely a section of the old high school sawed off and nailed together with a strip similarly sawed off from the elementary school. This conception spells failure in advance. There is particularly a tendency to copy the old high-school plan, with its vices as well as its virtues. As a result of our last year's experience it is my observation that teachers who have had university training but have been doing elementary-school work come nearer grasping the junior high-school ideal and realizing it than do teachers whose only experience within recent years has been in high-school work.

The junior high school is no get-rich-quick scheme in educational life. It is no cure-all nostrum for educational ills. In Houston, at any rate, it is merely a comparatively new educational institution which, so far as it has gone, has made good and which we believe will in the years to come with patient, honest, intelligent effort make good yet more abundantly.

It may be added that the junior high school, instead of causing still more breaks in the educational process, serves to draw attention to the unity of our entire system. It has not been an unmixed 
evil that in some of our more remote school buildings we have found it necessary to retain some of our seventh grades, or that it has been necessary to have some sixth-grade pupils in one of our junior high schools. It has not even been altogether an evil that we have some second-year high-school pupils in our senior highschool building. This emphasizes the idea that all our various schools form but one system. When pupils leave our junior high schools we give them certificates of the work completed, but not diplomas. We follow the same plan with pupils leaving the elementary schools. The junior high school is merely one distinct section in the work being done in the unity of the system. 